解 説

\title{
ダイナミックな界面現象のその場観察を通じた 水素エネルギー社会への応用
}

\author{
松 島 永 佳 $^{\mathrm{a}}$ \\ a 北海道大学 大学院工学研究院 ( $\mathrm{T}$ 060-8628 北海道札幌市北区北 13 条西 8 丁目) \\ In-Situ Observation of Dynamic Interfacial Phenomena for Application \\ to Hydrogen Energy Society
}

Hisayoshi MATSUSHIMA ${ }^{\text {a }}$

${ }^{a}$ Faculty of Engineering, Hokkaido University (Kita 13, Nishi 8, Kita-ku, Sapporo-shi, Hokkaido 060-8628)

Keywords : Water Electrolysis, Fuel Cell, SPM, Hydrogen Isotope Separation

\section{1. はじめに}

水電解や燃料電池など電気化学反応を利用した水素エネル ギーデバイスでは，電極 / 電解質との異相界面が存在する。 高効率かつ高耐久な電極触媒の開発には, 正確な表面構造解 析と高度な表面制御が極めて重要である。そこでは，1)電解 過程で「いつ, どこで, 何が起きているか」を原子・分子レ ベルの視点から理解し, 2) 理想的な表面構造の指針を考え, 3) どの様に創成するか, という動的 (ダイナミック)な考察が重 要である。

ここでは, 水素エネルギー社会の実現に向け「鍵」となる 基礎的研究について, プローブ顕微鏡 (SPM)を活用した気泡 発生観察や電極表面変化, さらには水素同位体分離の研究を ご紹介する。

\section{2. 原子間力顕微鏡によるナノ気泡観察}

水素製造として水電解は, 最も注目されている技術の一つ である。水電解は 1800 年頃に初めて発見された最も古い電 解プロセスであり，20世紀初頭に工業化された成熟した工 業技術である。しかし当時から電力消費量の問題があり，そ の大きな要因は気泡の存在である。気泡が電極面で発生する ことによる反応面積の低下, 電解液中に飛散することによる 空隙率の上昇，などを引き起こし電気抵抗の増加に繋がる ${ }^{1)}$ 。 これは, 現在, ナノサイズにまで触媒粒子が制御された固体 高分子型水電解においても問題とされている。そのため, ナ ノスケールで発生する気泡をオペランド観察することは, 触 媒への被覆率や劣化挙動を調べる上で重要である。本研究で は, 電気分解で発生した水素気泡を, 原子間力顕微鏡 $(\mathrm{AFM})$ を用いてその場観察を行った。

電極基板は，高配向性熱分解グラファイト (HOPG)を使用 し Ru触媒担持カーボンをその表面に分散させた。対極には 白金を使用し, 電解液は硫酸溶液 $\left(0.01 \mathrm{M} \mathrm{H}_{2} \mathrm{SO}_{4}\right)$ とし, 定電
流電解にて水電解を行った。AFM 測定は, ダイナミックモー ドにて走査範囲を 5〜10 $\mu \mathrm{m}$ とした。

電解開始前には，原子レベルで平滑である HOPG 表面に, 大きさが約数 $\mu \mathrm{m}$ の触媒担持カーボンが, 比較的均一に分散 していることが観察された(図 $1(\mathrm{~A}))$ 。電解を開始すると, 水素ナノバブルが発生し HOPG 表面全体を覆った(図 1 (B))。 画像解析から, このナノバブルのサイズは, 幅が 100 $200 \mathrm{~nm}$, 高さが 10 ～ $30 \mathrm{~nm}$ の扁平形状であることが分かった。 扁平な気泡形状は, 電解を伴わない研究においても多く報告 されており，ナノバブル特有と思われる ${ }^{2)}$ 。このように，ナ ノバブルは, 実際にマクロスケールで観察するバブルとは大 きく異なる可能性があり, 電極や触媒開発に重要な知見を与 えると考える。

\section{3. 水素発生反応における金属表面の動的変化}

金属表面で起こる水素発生反応は，ガス生成におけるメイ ンな機能とは別に, 金属腐食や水素脆化にも関わっており, この場合, 金属バルク中への水素吸蔵が重要な働きをすると 思われる。金属格子への水素侵入は, その中間体構造がある と報告されている ${ }^{3)}$ 。しかし, 実験的にガス発生環境下でそ

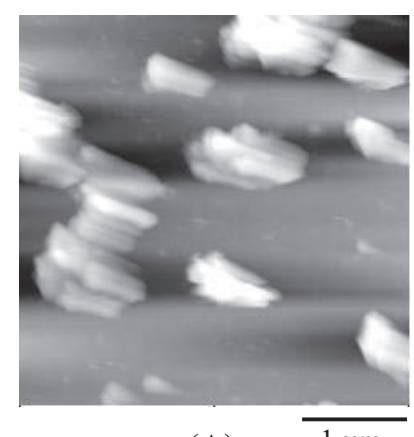

(A)

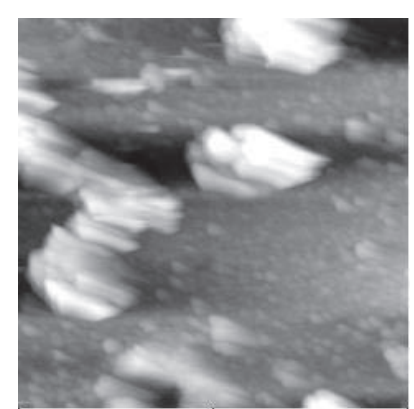

(B)
図 $1 \mathrm{AFM}$ による HOPG 基板表面の様子 ( (A) 電解前, (B) 電解中) 
の場観察する手法は難しく, 現状では電気化学的考察が主で ある。ここでは, 高速走査トンネル顕微鏡 (Video-STM)を用 いて, 水素発生反応での電極表面形態の変化を観察した ${ }^{4)}$ 。

電極基板には $\mathrm{Cu}(100)$ 単結晶, 対極には白金, 電解液は過 塩素酸水溶液 $\left(0.1 \mathrm{M} \mathrm{HClO}_{4}\right)$ を用いて, 定電位電解を行った。 Video-STM は，1秒あたり 30 frameまで取得可能であり，探 針にはポリプロピレンで被覆したタングステン針を使用した。

水素発生電位に変化させると, 瞬時 (0.1 秒以内) に stripe 構造の原子配列が観察された。この構造は [011］方向 (銅格 子と平行方向)に延び， stripe 間の最小間隔は $4 \cdot \mathrm{dCu}$ であった。 図 2 では, stripe 構造が銅基板格子に対し $0.35 \AA$ 隆起した 2 原子列で形成されている様がわかる。この隆起は, 吸蔵され た水素原子が銅原子を hollow site から bridge site に押し上げ たためと考えられる。最表面層の格子間隔を測定すると，水 素吸蔵原子によってその間隔が約 $20 \%$ 拡大していることが 分かった。連続写真(図 3)に示すように，この構造は電位変 化に対応して変化した。観察開始時点(水素発生電位より還 元電位)では，中央の $\mathrm{Cu}$ アイランドが角張った形状で，表 面が stripe 構造で覆われていた。電位を水素発生電位よりも 酸化電位側に変化させると, 表面の stripe 構造は消え, アイ ランドの先端部分の $\mathrm{Cu}$ が溶解し, 丸みを帯びた形状に変化 した。

Video-STM は, 気泡発生に伴う基板の摇れの影響を受けに くいため, 原子スケールで基板表面の変化を観察することが

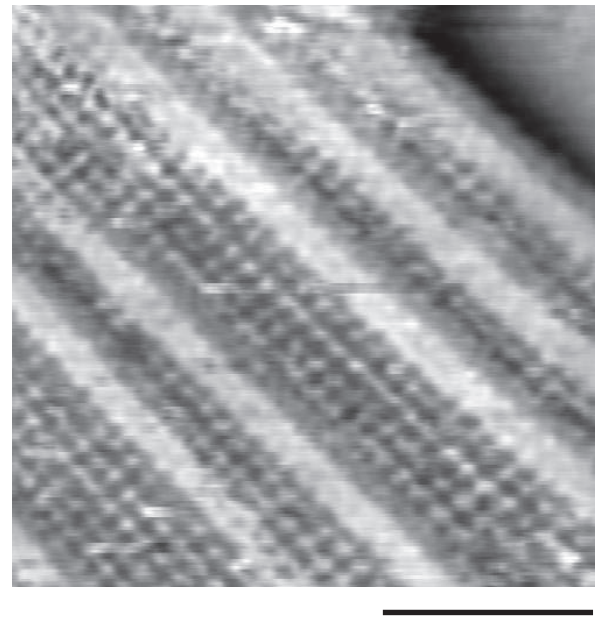

$2 \mathrm{~nm}$

図 2 Video-STM による水素発生中の $\mathrm{Cu}(100)$ 電極表面の様子

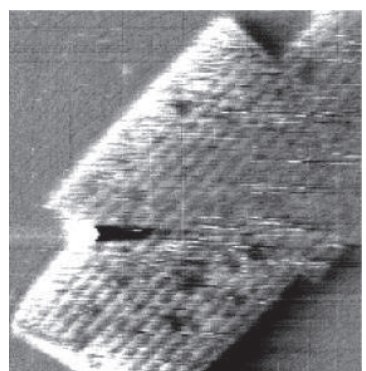

$0 \mathrm{~s}$

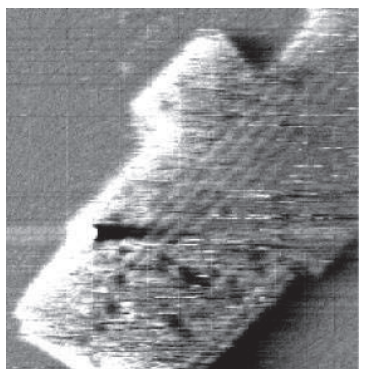

$0.4 \mathrm{~s}$

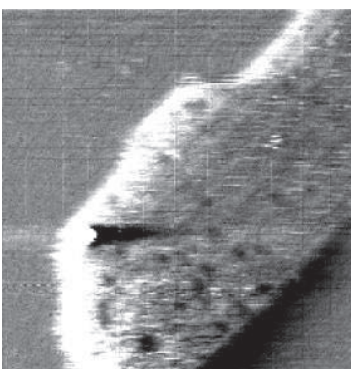

$0.8 \mathrm{~s}$

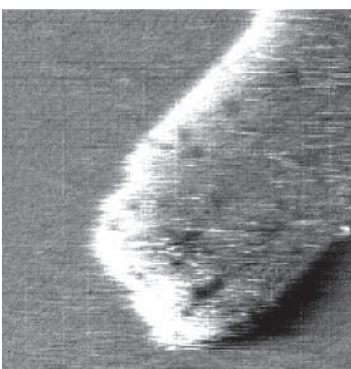

$1.2 \mathrm{~s}$

図 3 電位変化時における Video-STM による $\mathrm{Cu}(100)$ 電極表面の連続写真 
を使用した。AWEから発生する水素ガスを PEFC に供給し, 電解と発電での電気エネルギー差をシステム全体の消費電力 $\left(P_{\mathrm{T}}\right)$ として求めた。また, PEFCから排気される水素ガスを 質量分析計で分析し, 電解液の初期重水素濃度に対し何倍希 薄化されたかを，分離係数 $\left(\alpha_{\mathrm{T}}\right)$ を使って評価した。

図 4 は, $3 \mathrm{~A}$ で AWE を行った時の $P_{\mathrm{T}}$ と $\alpha_{\mathrm{T}}$ の関係を示す。 赤印のプロットは PEFC 発電量 $\left(P_{\mathrm{F}}\right)$ が $0 \mathrm{~W}$, すなわち水電解 のみの分離係数と消費電力を示す。発電量を増加させると, PEFC での分離効果も作用し， $\alpha_{\mathrm{T}}$ が増加した。今回の実験で は, 水電解単独と比較して D は 4 倍以上に希薄化 (電解液に 濃縮)されることが分かった。また，この時のエネルギー削 減率は $25 \%$ となり, 本手法では水電解法よりも低エネルギー かつ高効率の同位体分離が可能であることが示された。

\section{5. おわりに}

水素エネルギー社会では, 水電解や燃料電池で使われる金 属触媒が大切な要素となる。プローブ顕微鏡は, 通常では見 られないようなナノバブルなどユニークな基礎現象を解き明
かし, さらに高速プローブ曊微鏡によってダイナミックな表 面変化までも捉えることが可能となる。このようなオペラン ド観察は, 高活性かつ高耐久な触媒開発に繋がる知見を与え るであろう。また, 触媒表面構造と水素ガス発生反応を議論 することは, 将来, 水素同位体分離に適用される付加価值あ る新たな触媒開発にも展開すると考える。

(Received May 22, 2020)

\section{文献}

1) H. Matsushima, T. Nishida, Y. Konishi, Y. Fukunaka, Y. Ito, K. Kuribayashi ; Electrochim. Acta, 48, 4119 (2003).

2 ) S. Yang, P. Tsai, E. S. Kooij, A. Prosperetti, H. J. W. Zandvliet, D. Lohse ; Langmuir, 25, 1466 (2009).

3 ) G. Jerkiewicz; Prog. Surf. Sci., 57, 137 (1998).

4 ) H. Matsushima, C. Haak, A. Taranovskyy, Y. Gründera, O. M. Magnussena; Phys. Chem. Chem. Phys., 12, 13992 (2010).

5 ) R. Ogawa, R. Tanii, R. Dawson, H. Matsushima, M. Ueda ; Energy, 149, 98 (2018). 